\title{
BACTERIA ASSOCIATED WITH ENTERITIS IN BROILERS IN FAYOUM GOVERNORATE
}

\author{
"A.A.Moawad;" Mahmoud Essam Hatem and "Hammad Osama Hammad. \\ "Fac. Vet. Med.,KafrElsheikh Univ. \\ -" Fac. Vet. Med.,Cairo Univ. Animal Health Research institute Fayoum..
}

\begin{abstract}
600 samples were collected from diarrheic broiler chickens and from apparently normal chickens in Fayoum Governorate. The bacteriological examination revealed that a total of 530 bacterial isolates were recovered from the 600 broiler chickens under examination. Cloacal swabs (130), cecal contents (350), unabsorbed yolk sac (40), liver and gall bladder (40) and heart blood (40).

Concerning the type of isolated bacteria from broiler chickens $E$. coli was the predominate (59.3) \%. 53.3\% of isolates were from diarrheic birds and $6.0 \%$ from apparently healthy chickens, followed by Proteus mirabilis (14.8\%). Out of them were $11.6 \%$ from diarrheic birds and $3.2 \%$ from apparently healthy birds. And Proteus vulgaris (3.3\%). Out of them were $2.5 \%$ from diarrheic broiler chickens and $0.8 \%$ from apparently healthy one.

E. coli was the most predominant bacteria recovered from the examined cases. 50 isolates of E. coli which were isolated from large intestines tested for in vitro pathogenicity using Congo red dye. The result showed fundamental variation for the growth of E. coli of diarrheic and apparently healthy origin on Cango red dye as $86 \%$ of E. coli isolated from chickens gave red colonies (pathogenic) while $16 \%$ of E. coli isolates did not bind to Congo red dye gave white colonies (non pathogenic).
\end{abstract}


Eight E. coli isolates recovered from examined diseased broiler chickens were serotyped and revealed the following : 3 isolates 0114 K90, 2 isolates O26 K60, 2 isolates and one isolate O91 K - .

Ten Salmonella spp. isolates recovered from examined diseased broiler chickens were serotyped and revealed that 6 isolates were belonging to Salmonella Enteritidis and 4 isolates belonged to Salmonella Virchow.

Aeromonas hydrophila, Salmonella Enteritidis, Salmonella Virchow and E. coli were examined for antibiotic sensitivity test. It was found that Aeromonas hydrophila isolates were sensitive to gentamycin, doxycycline,norfloxacin,enrofloxacin, chloramphenicol and ciprofloxacin, Salmonella Enteritidis isolates were sensitive to chloromphenicol, enroloxacin, norfloxacin, colistin, ciprofloxacin and Gentamycin, neomycin and doxycycline, but Salmonella Virchow isolates were sensitive to chloromphenicol, enrofbxacin, norlooxacin, colistin, neomycin, ciprofloxacin, gentamicin, cephalexin and doxycycline, while E. coli isolates were sensitive to gentamicin, doxycycline and norfloxacin, chloramphenicol, cephalexin, norfloxacin and colistin.

Key Word: Enteritis, Broilers, Fayoum Governorate.

\section{INTRODUCTION}

Outbreaks of severe diarrhea followed by death which occurred every autumn for several years in 2 to 4 weeks old chicken on a poultry farm were recorded by $\mathrm{He}$ et al. (1981).

Verma and Adiakha (1971) isolated E. coli, Salmonella Anatum, Salmonella Stanly, Klebsiella species, Proteus species and paracolon bacteria from 359 chickens showing chronic respiratory disease, septicemia, unabsorbed yolk sac and enteritis. 
There is no doubt that Salmonella species are among the most important causative agents which infect poultry populations and cause great losses and hazards to public health (EL-Sayed, 1997).

Escherichia coli is a normal inhabitant of the intestinal tract of birds, these organisms are capable of producing diseases under the influence of predisposing factors, like inadequate and faulty ventilation, over crowding, thirst and extremes of temperature. Consequently, losses due to $\boldsymbol{E}$. coli infection occur as a result of high mortality during rearing and reduced weight gain (Kaul et al., 1992).

Family Enterobacteriaceae, which is composed of numerous interrelated Gram negative and oxidase negative bacteria, may constitute a great hazard to poultry industry. Some of them like Klebsiella assume a great significance. Many Klebsiella species are intestinal pathogens or commensals, while a few species are saprophytic mainly in the soil, water and feed rations (Arora et al., 1986). As Klebsiella group is concerned, it comprises many important species associated with diseases in birds, animals as well as human beings (Mackay, 1988). The Klebsiella organisms are known to play an important role as etiological agent of various diseases in birds and are found to be associated with different diseases as respiratory affections, septicemia, peritonitis, salpingitis, air sacculitis, omphalitis, arthritis, panophthalimitis and intestinal disturbances resulting in high mortality rates in young bird an decrease in egg production and hatchability of the infected eggs (Plesser et al., 1975; Mahalingam et al., 1988 and Rennie et al., 1990).

Proteus species were isolated from recently dead broilers chicks with an incidence of 25.8\% (Mahmoud and Moussa, 2000). 


\section{MATERIAL AND METHODS}

\section{Samples:}

A total of 600 broiler chickens from different farms at Fayoum governorate were subjected to bacteriological examination in the present investigation, Out of which 500 chickens were suffeed from enteritis and showed dullness, huddling, ruffled feather, diarrhea and low body gain. The rest of 100 broiler chickens were apparently healthy chickens from the same farms and were used as controls.

Table (1): Number of examined broiler chickens in different farms at Fayoum governorate.

\begin{tabular}{||l||c|c||c||}
\hline \multirow{2}{*}{\multicolumn{1}{|c||}{ Farms }} & \multicolumn{2}{c||}{ Number of examined birds } & \multirow{2}{*}{ Total } \\
\cline { 2 - 4 } & Apparently healthy & Diarrheic & \\
\hline \hline Tamia & 30 & 150 & 180 \\
\hline Senores & 30 & 150 & 180 \\
\hline Itsa & 20 & 100 & 120 \\
\hline Ibshawi & 20 & 100 & 600 \\
\hline Total & 100 & 500 & 120 \\
\hline \hline
\end{tabular}

Table (2): Distribution of samples collected from broiler chickens.

\begin{tabular}{|c||c||c||c||c||c||}
\hline samples & $\begin{array}{c}\text { Intestinal } \\
\text { swabs }\end{array}$ & $\begin{array}{c}\text { Cecum } \\
\text { contents }\end{array}$ & $\begin{array}{c}\text { unabsorbed } \\
\text { yolk sac }\end{array}$ & $\begin{array}{c}\text { Liver and } \\
\text { gall } \\
\text { bladder }\end{array}$ & $\begin{array}{c}\text { Heart } \\
\text { blood }\end{array}$ \\
\hline \hline 600 & 130 & 350 & 40 & 40 & 40 \\
\hline
\end{tabular}

Media used for bacteriological isolation:

The media used in the present study were:

\section{Transport medium:}

Stuart transport media (Oxoid)

\section{Liquid media:}

\section{Pre-enrichment medium:}

$1 \%$ buffered peptone water (Oxoid) 


\section{Salmonella enrichment media:}

\section{Selenite F-broth (Oxoid):}

It is a selective medium for isolation of salmonella:

\section{Selective solid media for plating:}

MacConkey's bile salt lactose agar medium (Oxoid):

A selective medium to differentiate between coliforms and nonlactose fermenters with inhibition of Gram-positive organisms.

Salmonella - Shigella (SS) agar (Oxoid):

It was used as a differential selective medium for the isolation of Salmonella from clinical specimens.

\section{Xylose lysine deoxycholate (XLD) agar (HIMEDIA):}

It was used as a differential selective medium for the isolation of Salmonella from clinical specimens.

Aeromonas agar base (Oxoid):

It was used as a differential selective medium for the isolation of Aeromonas from clinical specimens

\section{Congo red medium (Berkhoff and Vinal, 1986):}

It was used for differentiation between pathogenic and non pathogenic $\boldsymbol{E}$. coli. The medium consist of trypticas esoya agar (Oxoid) supplemeted by $0.03 \%$ Congo red dye (Sigma) and $0.15 \%$ bile salts (Sigma).

\section{Media used for biochemical reactions:}

All media used were prepared according to Cruickshank et al. (1975). 
- Peptone water 2\% (Oxoid) :

It was used for detection of indole production using Kovac's reagent.

- Glucose phosphate broth:

It was used for Methyl red (MR) reaction and Voges proskauer (VP) test.

- Simmon's citrate agar (Oxoid):

It was used for citrate utilization test.

- Christensen's urea agar base (Oxoid):

It was used for testing urease enzyme activity.

- Soft agar medium (0.5 \%):

It was used for detection of motility as well as short term preservation of isolates.

\section{- Triple sugar Iron agar (TSI) (Oxoid):}

It was used for detection of hydrogen sulphide production as well as fermentation of glucose, lactose and sucrose by change in butt and slants.

- Reagents and chemicals:

1. Kovac's reagent for indol test :

2. Tetramethyl-P-Phenylene diamine dihydrochloride 1\%: Solution was used for Oxidase test.

3. Methyl red 0.04\%:Solution was used for Methyl red test.

4. Voges Proskauer reagents (VP).

5. Sterile urea solution $40 \%$ :

It was added to Christensen's urea agar base (Oxoid) and used for urease test. 


\section{Gram stain.}

7.Phosphate buffer saline (PBS): It was used for serotyping of Salmonella.

8. Hydrogen peroxide 3.0\%: It was used for catalase test.

\section{Material used for API 20 E test :}

\section{- Media and reagents :}

- $5 \mathrm{Ml}$ of $\mathrm{NaCl} 0.85 \%$ medium, TDA reagent, JAMES reagent, VP 1 reagent, VP 2 reagent, NIT 1 reagent, NIT 2 reagent and 25 API 20 E strips

- 25 incubation boxes, 25 result sheets, 1 clip seal, pipettes, Ampoule protector and general microbiology equipment.

\section{Material used for antibiogram determination:}

Nutrient broth (Oxoid), Muller Hinton agar (Oxoid) and Antibacterial disks used for sensitivity test (Oxoid).

Antisera used for serotyping of E.coli isolates: (SIFIN Institut Berlin, Germany) .

- Available polyspecific products:

○ Anti-Coli I, Anti-Coli II and Anti-Coli III

\section{- Available monospecific products:}

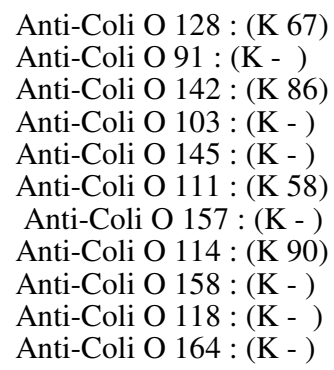

Anti-Coli O 25 : (K 11)

Anti-Coli O 119: (K 69)

Anti-Coli O 26 : (K 60)

Anti-Coli O 124 : (K 72)

Anti-Coli O 44: (K 74)

Anti-Coli O 125 : (K 70)

Anti-Coli O 55 : (K 59)

Anti-Coli O 126 : (K 71)

Anti-Coli O 78: (K 80)

Anti-Coli O 127 : (K 63)

Anti-Coli O 86 : (K 61) 
Antisera used for serotyping of Salmonella isolates:

(MAST ASSURE SALMONELLA ANTISERA Mast Diagnostic Mast House, Derby Road, Bootle, L20 1EA.)

Liquid stable antisera for the determination of $\mathrm{O}, \mathrm{H}$ and $\mathrm{Vi}$ antigens for the serological identification of Salmonellae.

\section{$\underline{\text { Methods }}$}

\section{Collection of samples:}

(Edward's and Ewings (1972), Finegold and Martin (1982) and Krieg and Holt (1984)).

All samples of chickens from different farms in Fayoum governorate (Tables 1 and 2) were collected and transported in an ice box to the laboratory as soon as possible, Swabs were collected in Stuart medium and transported in an ice box to laboratory as soon as possible, then inoculated in $10 \mathrm{ml}$ sterile buffered peptone water and incubated at $37^{\circ} \mathrm{C}$ for 24 hours incubation, About one $\mathrm{ml}$ was transferred to $10 \mathrm{ml}$ selenite$\mathrm{F}$ broth then incubated at $37^{\circ} \mathrm{C}$ for $18-24$ hours. A loopful from the selenite- F broth inoculated with the samples was streaked onto Salmonella Shigella (S.S.) agar and Xylose lysine deoxycholate (XLD) agar then incubated at $37^{\circ} \mathrm{C}$ for 24 hours. Each separate loopful was directly inoculated into separate nutrient broth tubes and then subcultured onto MacConkey agar. The inoculated broth and the streaked agar medium was incubated at $37^{\circ} \mathrm{C}$ for 24 hours. Pure colonies were picked up and preserved on slope agar for further morphological, biochemical and serological identification 
Bacteria Associated With Enteritis In Broilers In Fayoum Governorate.

Isolation of E. coli, Klebsiella pneumoniae, Pseudomonas spp., Proteus spp. and Aeromonus hydrophila by direct plating method: (Cruickshank et al., 1975).

Fecal samples were subjected for bacteriological examination.

Identification of bacterial isolates: (Cruickshank et al., 1975).

Morphological identification and detection of motility: (Cruickshank et al., 1975).

Biochemical identification by conventional methods : (Quinn et al. (2002); Koneman et al. (1995) and Finegold and Martin (1982) were using the following tests: Oxidase test, Catalase test, Indole test, Methyl red test (MR), Voges-Proskauer test (VP),Citrate utilization test, Urea hydrolysis test, Hydrogen sulphide test,as well as fermentation of glucose, lactose and sucrose by change in butt and slants .

Biochemical identification by API $20 \mathrm{E}$ test: (BioMerieux Sa France)

In-vitro antibiotic sensitivity of Aeromonas, Salmonella spp. and E. coli isolates: (Finegold and Martin (1982)).Reading of the results was interpreted according to NCCLS (2002).

\section{Serological typing of isolated bacteria:}

It was done at the National Laboratory for Veterinary Quality Control of Poultry Production (N.L.Q.P.) Dokki, Giza.

1- Serological identification of E. coli : Ewing (1986).

2- Serological identification of Salmonella serovars: (Kauffman, 1974) 


\section{RESULTS}

Incidence of bacteria isolated from diarrheic chickens and apparently healthy chickens:

\begin{tabular}{||c||c|c||c|c||c|c||}
\hline \hline \multirow{2}{*}{ M.O. } & \multicolumn{2}{|c||}{$*$ AHC } & \multicolumn{2}{c||}{$* *$ DC } & \multicolumn{2}{c||}{ Total } \\
\cline { 2 - 7 } & NO. & \% & NO. & \% & NO. & \% \\
\hline \hline E. coli & 36 & 6.0 & 320 & 53.3 & 356 & 59.3 \\
\hline $\begin{array}{c}\text { Proteus } \\
\text { mirabilis }\end{array}$ & 19 & 3.2 & 70 & 11.6 & 89 & 14.8 \\
\hline Salmonella spp. & - & - & 31 & 5.2 & 31 & 5.2 \\
\hline $\begin{array}{c}\text { Proteus } \\
\text { vulgaris }\end{array}$ & 5 & 0.8 & 15 & 2.5 & 20 & 3.3 \\
\hline $\begin{array}{c}\text { Aeromonas } \\
\text { hydrophila }\end{array}$ & - & - & 19 & 3.2 & 19 & 3.2 \\
\hline $\begin{array}{c}\text { Klebsiella } \\
\text { Pneumoniae }\end{array}$ & - & - & 15 & 2.5 & 15 & 2.5 \\
\hline $\begin{array}{c}\text { Pseudomonas } \\
\text { spp. }\end{array}$ & - & - & 14 & 2.3 & 14 & 2.3 \\
\hline \hline Total & $\mathbf{6 0}$ & $\mathbf{1 0 . 0}$ & $\mathbf{4 8 4}$ & $\mathbf{8 0 . 6}$ & $\mathbf{5 4 4}$ & $\mathbf{9 0 . 6}$ \\
\hline \hline
\end{tabular}

$* \mathrm{AHC}=$ Apparently healthy. $\quad * * \mathrm{DC}=$ Diarrheic.

Table (3): Results of bacteriological examination.

Incidence of different mixed bacteria isolated from diarrheic chickens:

\begin{tabular}{|c||c|c||}
\hline \multicolumn{1}{|c||}{ Mixed bacteria } & \multicolumn{2}{|c||}{} \\
\cline { 2 - 3 } & NO. & $\%$ \\
\hline \hline E. coli + Salmonella spp. & 8 & 1.3 \\
\hline E. coli + A. hydrophila. & 6 & 1.0 \\
\hline E. coli + Klebsiella pneumoniae. & 6 & 1.0 \\
\hline E. coli + P. Mirabilis. & 22 & 3.6 \\
\hline E. coli + P. vulgaris. & 9 & 1.5 \\
\hline E. coli + Pseudomonas pneumoniae. & 6 & 1.0 \\
\hline Salmonella spp. + A. Hydrophila. & 3 & 0.5 \\
\hline Salmonella spp. + P.mirabilis. & 12 & 2.0 \\
\hline A. hydrophila + P. mirabilis. & 4 & 0.6 \\
\hline Klebsiella pneumoniae + P. mirabilis. & 6 & 1.0 \\
\hline A. hydrophila. + P. vulgaris. & 3 & 0.5 \\
\hline Total & 85 & 14.16 \\
\hline \hline
\end{tabular}

Kafrelsheikh Vet. Med. J. Vol. 7 No. 1 (2009) 
Bacteria Associated With Enteritis In Broilers In Fayoum Governorate.

Table (4): Type of mixed bacteria among examined chicken.

Incidence of bacteria isolated from different organ of diarrheic chickens:

\begin{tabular}{||c||c||c||c||c||c||c||}
\hline & $\begin{array}{c}\text { Intestinal } \\
\text { Swabs }\end{array}$ & $\begin{array}{c}\text { Cecum } \\
\text { contents }\end{array}$ & $\begin{array}{c}\text { Unabs. } \\
\text { Yolk sac }\end{array}$ & $\begin{array}{c}\text { Liver \& } \\
\text { G.B. }\end{array}$ & $\begin{array}{c}\text { Heart } \\
\text { blood }\end{array}$ & Total \\
\hline \hline E. coli & 56 & 196 & 14 & 28 & 26 & 320 \\
\hline P. mirabilis & 17 & 33 & 10 & 5 & 5 & 70 \\
\hline $\begin{array}{c}\text { Salmonella } \\
\text { Spp. }\end{array}$ & 0 & 31 & 0 & 0 & 0 & 31 \\
\hline $\begin{array}{c}\text { P. vulgaris } \\
\text { A. hydrophila }\end{array}$ & 11 & 5 & 3 & 0 & 0 & 19 \\
\hline $\begin{array}{c}\text { Klepsiella } \\
\text { pneumoniae }\end{array}$ & 1 & 0 & 4 & 6 & 4 & 15 \\
\hline $\begin{array}{c}\text { Pseudomonas } \\
\text { spp. }\end{array}$ & 2 & 2 & 3 & 5 & 2 & 14 \\
\hline \hline \begin{tabular}{c} 
Total \\
\hline \hline
\end{tabular} & $\mathbf{9 3}$ & $\mathbf{2 7 5}$ & $\mathbf{3 5}$ & $\mathbf{4 4}$ & $\mathbf{3 7}$ & $\mathbf{4 8 4}$ \\
\hline
\end{tabular}

G.B.= gall bladder

Table (5): Recovered bacteria isolated from different diarrheic chicken organs.

Congo red binding activity of recovered E. coli:

\begin{tabular}{||l||c|c||c|c||c|c||}
\hline \multirow{2}{*}{ Congo Red Binding } & \multicolumn{2}{c||}{$*$ AHC } & \multicolumn{3}{c||}{ Total DC } \\
\cline { 2 - 8 } & AH & $\%$ & D & \% & Total & \\
\hline \hline Positive & 3 & 6 & 40 & 80 & 43 & 86 \\
\hline Negative & 7 & 14 & 0 & 0 & 7 & 14 \\
\hline \hline Total examined & $\mathbf{1 0}$ & $\mathbf{2 0}$ & $\mathbf{4 0}$ & $\mathbf{8 0}$ & $\mathbf{5 0}$ & $\mathbf{1 0 0}$ \\
\hline
\end{tabular}

$*$ AHC $=$ Apparently healthy $\quad * *$ DC $=$ Diarrheic 
Table (6): Results of in vitro differentiation between pathogenic and non pathogenic E. coli.

Antibiotic susceptibility of isolates to chemotherapeutic agents:

Antibiotic susceptibility of Aeromonas hydrophila isolated from diseased chicks:

\begin{tabular}{||l||c|c||c|c||c|c||}
\hline \multirow{2}{*}{ Antibacterial agents } & \multicolumn{2}{c||}{$* \mathbf{S}$} & \multicolumn{2}{c||}{$* * \mathbf{I}$} & \multicolumn{2}{c||}{$* * * \mathbf{R}$} \\
\cline { 2 - 7 } & $\mathbf{N 0}$ & $\boldsymbol{\%}$ & $\mathbf{N o}$ & $\%$ & No & $\%$ \\
\hline \hline \multirow{2}{*}{ Amoxicillin } & 1 & 25 & 1 & 25 & 2 & 50 \\
\hline Ampicillin & 1 & 25 & 1 & 25 & 2 & 50 \\
\hline Chloramphenicol & 3 & 75 & 1 & 25 & 0 & 0 \\
\hline Cephalexin & 1 & 25 & 2 & 50 & 1 & 25 \\
\hline Ciprofloxacin & 3 & 75 & 1 & 25 & 0 & 0 \\
\hline Enrofloxacin & 4 & 100 & 0 & 0 & 0 & 0 \\
\hline Neomycin & 1 & 25 & 1 & 25 & 2 & 50 \\
\hline Gentamicin & 4 & 100 & 0 & 0 & 0 & 0 \\
\hline Doxycycline & 4 & 100 & 0 & 0 & 0 & 0 \\
\hline Norfloxacin & 4 & 100 & 0 & 0 & 0 & 0 \\
\hline Erythromycin & 1 & 25 & 1 & 25 & 2 & 50 \\
\hline Colistin & 1 & 25 & 2 & 50 & 1 & 25 \\
\hline
\end{tabular}

$* \mathrm{~S}=$ Sensitive $\quad * * \mathrm{I}=$ Intermediate $\quad * * * \mathrm{R}=$ Resistant

Table (7): The results of disc diffusion test on A. hydrophila isolates.

Antibiotic susceptibility of Salmonella Enteritidis and Salmonella Virchow isolated from diseased chickens:

\begin{tabular}{|c|c|c|c|c|c|c|c|c|c|c|c|c|}
\hline \multirow{3}{*}{$\begin{array}{c}\text { Antibacterial } \\
\text { agents }\end{array}$} & \multicolumn{6}{|c|}{ S. Enteritidis } & \multicolumn{6}{|c|}{ S. Virchow } \\
\hline & \multicolumn{2}{|c|}{$* \mathbf{S}$} & \multicolumn{2}{|c|}{$* * \mathbf{I}$} & \multicolumn{2}{|c|}{$* * * \mathbf{R}$} & \multicolumn{2}{|c|}{$* \mathbf{S}$} & \multicolumn{2}{|c|}{$* * \mathbf{I}$} & \multicolumn{2}{|c|}{$* * * \mathbf{R}$} \\
\hline & No & $\%$ & No & $\%$ & No & $\%$ & No & $\%$ & No & $\%$ & No & $\%$ \\
\hline Amoxacillin & $\overline{1}$ & 25 & $\overline{1}$ & 25 & $\overline{2}$ & $\overline{\overline{50}}$ & $\overline{\overline{0}}$ & $\overline{\overline{0}}$ & $\overline{3}$ & $\overline{\overline{75}}$ & $\overline{1} 1$ & $\overline{25}$ \\
\hline Ampicillin & 0 & 0 & 1 & 25 & 3 & 75 & 0 & 0 & 1 & 25 & 3 & 75 \\
\hline $\begin{array}{l}\text { Chloram- } \\
\text { phenicol }\end{array}$ & 4 & 100 & 0 & 0 & 0 & 0 & 4 & 100 & 0 & 0 & 0 & 0 \\
\hline Cephalexin & 1 & 25 & 2 & 50 & 1 & 25 & 2 & 50 & 1 & 25 & 1 & 25 \\
\hline Ciprofloxacin & 4 & 100 & 0 & 0 & 0 & 0 & 4 & 100 & 0 & 0 & 0 & 0 \\
\hline Neomycin & 3 & 75 & 1 & 25 & 0 & 0 & 4 & 100 & 0 & 0 & 0 & 0 \\
\hline Gentamicin & 4 & 100 & 0 & 0 & 0 & 0 & 4 & 100 & 0 & 0 & 0 & 0 \\
\hline Doxycycline & 3 & 75 & 1 & 25 & 0 & 0 & 2 & 50 & 1 & 25 & 1 & 25 \\
\hline Norfloxacin & 4 & 100 & 0 & 0 & 0 & 0 & 4 & 100 & 0 & 0 & 0 & 0 \\
\hline Erythromycin & 0 & 0 & 1 & 25 & 3 & 75 & 0 & 0 & 1 & 25 & 3 & 75 \\
\hline Colistin & 4 & 100 & 0 & 0 & 0 & 0 & 4 & 100 & 0 & 0 & 0 & 0 \\
\hline
\end{tabular}

$$
* \mathrm{~S}=\text { Sensitive } \quad * * \mathrm{I}=\text { Intermediate } \quad * * * \mathrm{R}=\text { Resistant }
$$


Bacteria Associated With Enteritis In Broilers In Fayoum Governorate.

Table (8): The results of disc diffusion test on Salmonella Enteritidis and Salmonella Virchow.

Antibiotic susceptibility of E. coli isolated from diseased chickens:

\begin{tabular}{||l||c|c||c|c||c|c||}
\hline \multirow{2}{*}{\multicolumn{1}{|c||}{ Antibacterial agents }} & \multicolumn{2}{c||}{$* \mathbf{S}$} & \multicolumn{2}{c||}{$* * \mathbf{I}$} & \multicolumn{2}{c||}{$* * \mathbf{R}$} \\
\cline { 2 - 7 } & N0 & $\%$ & No & $\%$ & No & $\%$ \\
\hline \hline Amoxicillin & 1 & 25 & 2 & 50 & 1 & 25 \\
\hline Ampicillin & 0 & 0 & 1 & 25 & 3 & 75 \\
\hline Chloram-phenicol & 3 & 75 & 1 & 25 & 0 & 0 \\
\hline Cephalexin & 3 & 75 & 1 & 25 & 1 & 25 \\
\hline Ciprofloxacin & 1 & 25 & 2 & 50 & 1 & 1 \\
\hline Enrofloxacin & 3 & 75 & 1 & 25 & 0 & 0 \\
\hline Neomycin & 0 & 0 & 1 & 25 & 3 & 75 \\
\hline Gentamicin & 4 & 100 & 0 & 0 & 0 & 0 \\
\hline Doxycycline & 4 & 100 & 0 & 0 & 0 & 0 \\
\hline Norfloxacin & 4 & 100 & 0 & 0 & 0 & 0 \\
\hline Erythromycin & 0 & 0 & 1 & 25 & 3 & 75 \\
\hline Colistin & 3 & 75 & 1 & 25 & 0 & 0 \\
\hline \hline
\end{tabular}

$* \mathrm{~S}=$ Sensitive $\quad * * \mathrm{I}=$ Intermediate $\quad * * * \mathrm{R}=$ Resistant

Table (9): The results of disc diffusion test on E. coli isolates.

Results of serological identification: Results of serological identification of $E$. coli isolates:

\begin{tabular}{|c|c|}
\hline Serotype & No of isolates \\
\hline \hline O114 K90 & 3 isolates \\
\hline O26 K60 & 2 isolates \\
\hline O126 K71 & 2 isolates \\
\hline O91 K - & one isolate \\
\hline Total & $\mathbf{8}$ isolates \\
\hline
\end{tabular}

Results of serological identification of Salmonella spp isolates:

\begin{tabular}{|c||c|}
\hline \multicolumn{1}{|c||}{ Serotype } & No of isolates \\
\hline \hline Salmonella Enteritidis & 6 isolates \\
\hline Salmonella Virchow & 4 isolates \\
\hline \hline Total & $\mathbf{1 0}$ isolates \\
\hline
\end{tabular}

Kafrelsheikh Vet. Med. J. Vol. 7 No. 1 (2009) 


\section{DISCUSSION}

In the present investigation 600 different samples were collected from diarrheic and apparently healthy broiler chickens in Fayoum governorate. The recovered bacterial isolates were $\boldsymbol{E}$. coli $(59.3 \%)$, Proteus mirabilis (14.8\%), Salmonella spp. (5.2\%), Proteus vulgaris (3.3), Aeromonas hydrophila (3.2\%), Klebsiella spp. (2.5\%) and Pseudomonas spp. $(2.3 \%)$.

E. coli was isolated in high incidence which agrees with Khalid (1990), Mukhopadhyaya and Mishra (1992), El-Gaber and El-Gohary (1995), Emad (1996), Mahmoud and Moussa (2000) and Abeer (2004) who isolated $E$. coli with incidences of $57.6 \%, 59.8,59 \%, 62 \%, 60 \%$ and $55.6 \%$ respectively. While higher incidences of $\boldsymbol{E}$. coli were recovered by El-Sukhon (1990), Sara et al. (1995), Salman (1999), Gomis et al. (2000) and Farghaly (2000) who recovered 67.7\%, 100\%, 73.3\%, $67.2 \%$ and $72.9 \%$ isolation rates, respectively.

These variations may be attributed to the pathogenicity of $\boldsymbol{E}$. coli for chickens which had been correlated with numerous extrinsic and intrinsic bird related factors and conditions. These extrinsic factors include environmental conditions, exposure to other infections agents, virulence of bacteria, levels and duration of exposure, while the intrinsic factors affecting susceptibility of the bird include age, route of exposure, active and passive immune status and bread of chickens (Deb and Harry, 1976; Gaven, 1978 and Suelam, 2003).

Our study revealed also that Salmonella spp. Isolated with an incidence of 5.2\% this result agree with Shouman and Moustafa (1972), Lu et al. (1986), Venkana et al. (1996), Jindal et al. (1999) and 
Mohamed (2003) who recovered Salmonella in incidences of $3.6 \%$, $4.4 \%, 6.3 \%, 5 \%$ and $4 \%$, respectively. Lower recovery rates were obtained by Bayoumi et al. (1979), El-kady (1986), El-Gohary (1989) and Kim et al. (2003) who recovered Salmonella in incidences of $1.6 \%$, $0.8 \%, 0.74 \%$ and $1.6 \%$, respectively. Higher results obtained by $\boldsymbol{A b d} \mathbf{E l}$ Galil et al. (1983), Emad (1996), EL-Morsi (1998), Mahmoud and Mousa (2000), Suelam (2003), Amen (2004), Rehan (2004) and Abeer (2004) who recovered Salmonella in incidences of $25 \%, 10 \%, 12 \%$, $9.17 \%, 9.8 \%, 18.8 \%, 12 \%$ and $18.8 \%$ respectively.

Aeromonas hydrophila was recovered in the present study in an incidence of $3.2 \%$ which agree with that recovered by Glunder (1988) and Ahmed (2004) who recovered A. hydrophila in incidences of $3.6 \%$ and $2.33 \%$, respectively.

Proteus spp. were recovered in an incidence of $18.1 \%$ which is more or less similar to Taha (2002), Suelam (2003) and Abeer (2004) who isolated it with incidences of $15 \%, 15.5 \%$ and $14.9 \%$, respectively, while lower rate was obtained with Sarma et al . (1985) (10.6\%) and higher rate was recovered by Mohamed (1994) (25.77\%).

Klebsiella spp. were recovered in an incidence of $2.5 \%$ which is relatively in agreement with Abd El-Galil et al. (1983) Osman (1992) Abd El-Motelib El-Zanaty (1993) Taha (2002) and Suelam (2003) who isolated it in incidences of 3\%,4\%, 4.8\%, $4.3 \%$ and $3.4 \%$, respectively. while lower rate was obtained by Flamer and Drewes (1988)(0.6\%) and higher rates were obtained by Niazi et al. (1981), Ann et al. (1982), Ali et al. (1984), Choudhury et al. (1993), Zakhary (1998) and Abeer (2004) who recorded isolation rates of $27.64 \%, 27 \%, 7 \%, 8.2 \% 29.1 \%$, and $19.14 \%$, respectively. 
Pseudomonas spp. were recovered in an incidence of $2.3 \%$ which is in agreement with Awaad et al. (1981) and Osman (1992) who isolated it in incidences of $2.9 \%$ and $2 \%$, respectively. Relatively in agreement with Castro et al. (1989) Younes et al. (1990) Choudhury et al. (1993) who isolated it in incidences of 5\%, $4.9 \%$ and $4.7 \%$ respectively, while higher rates were obtained by Shahata et al. (1988) Venkanagouda et al. (1996) Emad (1996) Mahmoud and Moussa (2000) Shosha (2003) Suelem (2003) Abeer (2004) who recorded isolation rates of $18.2 \%, 6.06 \%, 8.7 \%, 6.7 \% 10 \%, 10.6 \%$ and $16.4 \%$, respectively.

As $\boldsymbol{E} . c o l i$ is a normal inhabitant in the intestinal tract of birds so, its isolation from feces of broiler (diarrheic or apparently healthy) have no significance unless determination if it was pathogenic or non pathogenic could be achieved, For this purpose Congo red binding activity of $\boldsymbol{E}$. coli isolates was determined in the present work. The results showed fundamental difference between the percentage of Congo red (CR) positive (red colored colonies) E. coli (pathogenic) (86\%) and Congo red (CR) negative (white colored colonies) E. coli (non pathogenic) (14\%).

The pattern of antibiotic susceptibility of the most prevalent intestinal pathogens was done in vitro and the obtained data revealed that Aeromonas hydrophila isolates were sensitive to gentamicin, doxycycline, norfloxacin, enrofloxacin chloramphenicol and ciprofloxacin. This is in agreement with Forbes et al. (1998), Kelley et al. (1998) and Altwegg (1999) and some whate agree with Ahmed (2004) but is in disagreement with the result given by El khashab and El yazed (2001).

Salmonella isolates were sensitive to chloromphenicol, enrofloxacin, norfloxacin, colistin, ciprofloxacin, gentamycin, neomycin and doxycycline. 
This results agree with Gyurov (1986), Wasniewski and Galazka (1992), Hoszowski et al. (1998) and Lakshmi et al. (2006) and is in disagreement with the result given by Hermans et al. (1996), Rzedzicid et al. (1997), Cormican et al. (2002) and Hernandez et al. (2002).

$\boldsymbol{E}$. coli isolates were sensitive to gentamycin, doxycycline and norfloxacin, chloramphenicol, cephalexin, enrofloxacin and colistin sulphate. This results agree with Ghosh (1987), Filali et al. (1988),( Khalid, 1990), Bebora et al. (1994), Gowda et al. (1996) and Vakani et al. (1997) and differ from those recovered by Cloud et al. (1985), Kaul et al. (1992), Amara et al. (1995) and Saenz et al. (2001).

This variation in results could be due to intensive haphazard antibiotics therapy usually given by owners in most cases of bacterial infections in broiler chicken farms especially in Fayoum governorate.

\section{REFERENCE}

- Abd El Galil, Y.; El Bakry, M. and Amara, A. (1983): Bacterial causes of early chicks mortalities in Sharkia Governorate.Proceeding $17^{\text {th }}$ world poultry congress, 557-558.

- Abeer, E. A. (2004): Bacterial causes of early mortality in broiles chicken.M.V.Sc. thesis (Microbiology) Fac. Of Vet. Med Tanta University.

- Ahmed, M.H. (2004): Studies on Aeromonas hydsophila in chickens.M.V.Sc thesis, Diseases of Birds and Rabbits. Fac. Vet. Med. Cairo Univ.

- Ali, A. B.; Jayaraman, M.S. and Purushothaman,V. (1984):A study on the aerobic bacteria associated with mortality in young chicks 0-2 weeks.Cheiron, 13 (4): 178-181. 
- Altwegg, M. (1999): Aeromonas and plesiomonas in Manual of clinical Microbiology ASM press Washington D.C.

- Amara, A.; Ziani, Z. and Bouzzoubaa, K. (1995): Antibiotic resistance of Escherichia coli strains isolated in Morocco from chickens with colibacillosis.Vet. Microbial., 43: 325-330.

- Amen, A. A. (2004): Bacterial causes of early mortality in broiler chicken.M.V.Sc. thesis, Fac. Vet. med., Kafr El-Sheikh.

- Ann, M.; Zeinab, M.N. and Osman, M.A (1982): Some pathological and bacteniological aspects of klebsiella infection in chickens.J. Egypt. Vet. Med Ass., 42 (2): 125-136.

- Arora, A. K. ; Gupta, S. C. and Kaushik, R. K. (1986): Detection of upper respiratory tract bacterial carriers in poultry.India. Vet. Med. J., 10 (2): 63 - 67.

- Awaad, M.; Youssef, Y.I.; Saad, F.E. and Sarakbi, T.M.B. (1981): Study of Pseudomonas aeruginosa in chickens.Vet. Med. J., 29: 135-143.

- Bayoumi, A.H.; shehta, M.A. and Sokkar, I.H. (1979): Studies on paratyphoid infections in chickens and ducks in upper Egypt. Assiut Vet. Med. J. , 6 (u/12): 129-145.

- Bebora, L.C.; Ovndo, J.O and yamamoto, H. (1994): Resistance of E. coli strains recovered from chickens to antibiotics with particular reference to trimethoprim-sulf methoxazole (septrin).East Afr J. 1994 Oct, 71 (10): 624-627

- Berkhoff, H.A. and vinal, A.C. (1986): Congo red medium to distinguish between invasive and non invasive Escherichia coli pathogenic for poultry. Av. Dis., 30(1), 117-121. 
- Castro, A.G.H.; Carvalho, A.H.; Hipolito, M.; Poludetti, A.; De Castro, A.G. and De Carvalho A.M. (1989): Mortality in chickens caused by Pseudomonas aeruginosa.Arque. Instit. Boil. Sao. Paulo., 56 Supl. 62.

- Choudhury, B.; Chanda, A.; Dasgupta, P.; Dutta, R.; Saha, L. and Bhuin, S. (1993): Studies on yolk sac infection in poultry.Indian J. Animal Health, 32 (1) : 21- 23.

- Cloud V.; Venugoplan, A.T. and Bloprokasam R.A. (1985): Scrotypes of E.coli strains isolated from pathological conditions of poultry.Cherions, Tamil Nadu journal of Vet. Science and Animal Itusbanadsy, 11 (3):146-148.

- Cormican, M.; Delapee, N.; Ohare, C.; Doran, G.; Morris, D.; Corbett, F.G.; Fanning, S.; Daly, M.; Fitzgerald, M. and Moore, J. (2002): Salmonella enterica serovares and antimicrobial susceptibility and molecular diversity of isolates from Ireland and Northen Ireland.Applied and Environmental Microbiol., 38 (1): 181186.

- Cruichshank, R.; Duguid, J.P.J; Marmion, B.P. and Swain, R.H.A. (1975): Medical Microbiology 12th ed. Volume II Churchill, living stone Edinburgh, London and New York.

- Deb, J.R. and Harry, L. (1976): Laboratory trials with inactivated vaccines against $\boldsymbol{E}$. coli (O78:K80) infection in fowls.Vet. Sci., 20: 131-138.

- Edwards, P. R. and Ewings, W. H. (1972): Identification of Enterobacteriacaea. $3^{\text {th }}$ ed. Bergey's publishing Co, Minneopoles. 
- El Gohary, A.A. (1989): Studies on the epidemiology of Salmonella Gallinarum Pullourm isolation and identification serologically and biochemically in newly hatched chicks.M.V.Sc. thesis, Fac. Vet. Med., Cairo Univ.

- El Kady, M. (1986): Studies on the S. Gallinaram pullorun infection in poultry Beni - Suef.M.V.Sc, thesis (poultry Diseases), Fac. Of Vet. Med. Cairo University.

- El Khashab, E.F. and EL Yazed, H.S.A (2001): Epidemiology of Aeromonas hydrophila infection in ducks transmitted from fish in duck fish farm. Beni-Suef Vet. Med. J.Xi (2):751-764.

- $\quad$ El Morsi, M.E.M. (1998): Occurrence of food poisoning organisms in poultry products with special reference to campylobacter. Ph.D. thesis (Meat Hygiene),Fac. Vet . Med., Zagazig Univ.

- EL Sayed, E. A. E. (1997): Salmonella in food.Ph.D. thesis (Bacteriology, immunology and Mycology), Fac. Of Vet. Med. ,Cairo University.

- El Sukhon, S.N. (1990): Incidence of Escherichia coli in chicken affections.Indian J. of Snimal Sci., 60(3):263-267.

- Emad A.A.M. (1996): Study in some bacterial causes of early chick mortalities in sharkia providence.M.V.Sc. thesis (poultry and rabbit diseases), Fac. of Vet. Md., Zagazig University.

- Ewing, W.H. ( 1986): Identification of Enterobacteriacaea. $4^{\text {th }}$ ed. Elsevier Science., New York. 
- Farghaly, E.M. (2000): Some studies on the virulence attributed to E. coli isolated from chickens from chickens in Assiut. M.V.Sc thesis (poultry and rabbit diseases), Fac of Vet. Med., Assuit University.

- Filali, E.; Bell, I.G.; Houadfi, M.; Uggins, M.B. and Cook, J.K. (1988): Antibiotic resistance of Escherichia coli strains isolated from chichkens with colisepticaemia in Morocco.Comp. Immune. Microbial. Infect. Dis., 11(2): 121-124.

- Finegold, S.M. and Martin, W.T. (1982): Diagnostic microbiology. $6^{\text {th }}$ ed. C. V. Mosby Company St. louis, Toronto.

- Flamer, K. and Drewes, L.A. (1988): Species related differences in the incidence of Gram-negative bacteria isolated from the cloacae of clinically normal psittacoses birds.Avian. Dis., 32: 79-83.

- Forbes, B.A.; Sahm, D.F. and Weiss Feld, A.S. (1998): In Bailey and Scott's diagnostic microbiology (tenth ed.)

- Gaven, E. (1978): Observation on expermintal infection of chicks with $\boldsymbol{E}$. coli.Avian pathology, 7: 312- 327.

- Ghosh, S.S. (1987): Occurrence of $\boldsymbol{E}$. coli serotypes in chicks in Nagaland.Indian Vet. J., 64:464-466.

- Glunder, G. (1988): Occuance of Aeromonas hydrophila in birds. J. Vet. Med. B 35: 331-337.

- Gomis, s.m.; Gomis, A.I.; Horadagoda, N.U.; Wijewardene, T.G.; Allan, B.J. and Potter, A.A. (2000):Studies on cellulites and other disease syndromes caused by Escherichia coli in broilers in Seri Lanka.Trop. Animal Health Prod., 32(6): 341-351. 
- Gowda, B.M.V.; Murthy, G.V.K.; Upadhye, A.S. and Raghavan, R. (1996): Serotypes of Escherichia coli from pathological conditions in poultry and their antibiogram.Indian Vet. J., 73:123-126.

- Gyurov, B. (1986): Sensitivity to drugs of Salmonella strains isolated from poultry between 1980-1984.Vet. Med. Nauki, 23 (1): $10-17$.

- He, W.M.; liu, H.J.; Ma, X.F. and Zhao, L.S. (1981): Diagnosis of necrotic enteritis in chicken.Chinese j. Vet. Med., 7 (11: 18-19).

- Hermans, P.W.; Saha,S.K.; Lecuwen, W.J.; Belkum, A.V. and Goessens, W.H. (1996): Molecular typing of Salmonella Typhi Strains and development of DNA identifying plasmid encoded multidrug resistant isolates.J. Clin. Microbiol.,34(6): 1373-1379.

- Hernandez, T.; Rodriguez, A. C.; Arevalo, M. P.; Torres, A.; Sierra, A. and Arias, A. (2002): Antimicrobial resistant Salmonella enterica serovar isolated from chicken in Spain.J. chemother., 14 (4): 346-350.

- Hoszowski, A.; WasyI, O. and Truzczynski, N. (1998): Drug resistance in Salmonella strains isolated from animals and animals feeds in Poland between 1994 and 1996 .Medycyna Veterinary J., 45 (I): 33-37.

- Jindal, N.; Raja, N.; Kumar, S.; Narag, G. and Mhjan, N. K. (1999): Salmonella Gallinarum and Salmonella Enteritidis infection in poultry in some parts in Haranya.Ind. Vet. J., 76 (6): 563-564.

- Kauffmann, F. (1974): Serological diagnosis of Salmonella species. Kauffmon-white Stanley V.G. 
- Kaul, L. ; Kaul, L.P. and Shah, N. M. (1992): An outbreak of colibacillosis in broiler chicks at an organized poultry farm under semi-arid zone of North Gujarat.Indian Vet. J., 69:373-374.

- Kelley, T.R.; Pancorbo, O.C.; Merka, W.C. and Barnhart, H. M. (1998): Antibiotic resistance of bacterial litter isolates.J. of poultry science 77 (2): 243-247

- Khalid, A. M. (1990): Studies on natural and experimental Escherichia coli infection in chickens. j. Egypt. Vet. Med Ass., 50 (3):379-389.

- Kim, k.; Jung, B. Y. and Kim, B. H. (2003): Prevalence of serotype and antimicrobial susceptibility of Salmonella spp. Isolated from domestic animals in Gyeongbuk providence.Korean J. Vet. Pub. Health, 27 (1) : 47 - 52.

- Koneman, E. W.; Allen, S. D.; Janda, W. M.; Schrecken berger, P. C. and Winn, W. C. (1995): Introduction to Diagnostic Microbiology.J. B. lipincott Company Philadelphia, U.S.A.

- Krieg, N. R. and Holt, J. G. (1984): Bergey's manual of systemic Bacteriology. Vol. 1. William and Wilkins Company. Baltimore, London.

- Lakshmi, V.; Ashok, R.; Susmita, J. and Shailaja, V.V. (2006): Changing trends in the antibiograms of salmonella isolates at atertiary care hospital in Hyberabad Ind. J. Med. Microbiology, 24 (I): 45-48. 
- Lu, Y. S.; Tsai, H. J.; Yang, S. Y.; Lin, D. F.; Lee, Y. L.; Lee, C. and Chiu, S. Y. (1986): Nervous symptoms in broiler chicks due to Salmonella Pullorum infections. J. Chin. Soc. Vet. Sci., 2(2): 143150.

- Mahalingam, P. ; Masillamony, P. R. ; Palaniswami, K. S. and Venugopalan, V. T. (1988): Virulence attributes of $\boldsymbol{E}$. coli and Klebsiella species isolates from hatcheries. Ind. Vet. J. , 65 (4): 283287.

- Mahmoud, A. E. A. and Moussa, H. M. (2000): Studies on some aerobic bacteria causing of broiler. $1^{\text {st }}$ scientific conference for provincial laboratories, Animal Health Research Instit. , 15-17 may 2000.Egyptian J. Agri. Res., 78(1): especial Issue,25-34.

- Mohamed, A. R. A. (1994): Studies on the occurrence of Proteus species in poultry with especial references to its antigenic relationship.Ph.D. thesis (Microbiology), Fac. of Vet. Med., Moshto for, Benha branch, Zagazig University.

- Mohamed, N. S. (2003): A survey of salmonella contamination in chicken carcass and giblets in Central Ethiopia. Revue de medicine Vet., 154 (4) : $267-270$.

- Mukhopadhyaya, B. N. and Mishra, S. K. (1992): Incidence of colibacillosis in chicks in some poultry pockets of west Bengal. Indian J. of poultry Science, 27(2):103-107. 
- National Committee for Clinical Laboratory Standards NCCLS, (2002): Performance Standards for Antimicrobial susceptibility testing.

- Niazi, Z. M., Abd El Ghani, M. and Nada, S. M. (1981): Bacteriological studies on Klebsiella spp. infections in chickens and developing chick emberyos. Agricultural. Rev., 59 (57) : 53-64.

- Osman, M. M.(1992): Studies on bacterial causes of early poultry mortality in Sharkia governorates. M.V.Sc, thesis (Microbiology), Fac. Of Vet. Med. Zagazig University.

- Plesser, O. ; Even-Shoshan, A. and Bendheim, U. (1975): The isolation of Klebsiella pneumoniae from poultry and hatcheries. Refuah Vet., 32 (3): 99 - 105.

- Quinn, P. J.; Carter, M. E.; Markey, B. K.; Donnelly, W. J. C. and Leonard, F. C. (2002): Veterinary Microbiology and Microbial diseases. MPG, Book. $1^{\text {st }}$ ed., Bodmin, Cornwall, UK.

- Rehan, H.M.A. (2004): Application of Pcr identification of Salmonella spp. in chickens.M.V.Sc., thesis, Fac. Vet. Med., Mansoura Univ.

- Rennie, R. P. ; Andeson, C. M. ; Weinsley, B.C.; Albritton, W. L. and Mahony, D. E. (1990): Klebsiella pneumoniae gastroenteritis masked by Clostridium perfringens. J. Clin. Microbiol., 28 (2) : 216219.

- Rzedzicki, J.; Bas, M. and Glinski, A. (1997): The in vitro acquired drug resistance of Salmonella Enteritidis isolated from poultry. Annals Universitiatis Mariae Curie Sklodwska Medicina Veterinaria, 52: $167-173$. 
- Saenz, Y.; Zarazaga, M.; Brinas, L.; Lantero, M.; Ruiz-Larrea, F. and Torres. (2001): Antibiotic resistance in Escherichia coli isolates obtained from animals, foods and humans in Spain. Int. J. Antimicrob. Agents, 18(4): 353-358.

- Salman, A.M. (1999): Serological and bacteriological studies on $\boldsymbol{E}$. coli in chickes. Ph.D., thesis (Microbiology), Fac. of Vet. Med., Cairo University.

- Sara, G. R.; sur; S. K., Mitra, M.; Nag, N. and Das, A.K. (1995): Colibacillosis in captive birds at Alipore Zoo.Indian J. of Animal Health, 34(1): 43-45.

- Sarma, D. R. L.; Char, N. L.; Rao M. R. K.; khan; D.I. and Naryana, G. (1985): A comprehensive study on bacterial flora isolated from yolk sec ingfections (ompholitis) in chicks. Indian J. poult. Science, 20 (4): 262-265.

- Shahata, M. A.; El-Tamawy, A. M. and Seddik, I. (1988): Occurrence of pseudomonas infection in upper Egypt.Assiut vet. Med. J., 20:168-177.

- Shosha, M. A. M (2003): Some studes on Pseudmonas infection in chicks.M.V.Sc., thesis (poultry and Rabbit Diseases), Fac. Of vet. Med., Zagazig University.

- Shouman, M.T. and Moustafa, F.M. (1972): Salmonellosis in chickens.Egypt. Vet. Med. J., 20, 183. 
- Suelem I. I. A. (2003): Bacteriological problems in broiler farms and its relation with productivity. M.V.Sc., thesis (Microbiology), Fac. Of Vet. Med., Zagazig University.

- Taha N. A. A. (2002): Zoonotic importance of enteropathogenic $\boldsymbol{E}$. Coli (EPEC). Ph. D., thesis (Zoonoses), Fac. Of Vet. Med., Zagazig University.

- Vakani, P.; Murthy, K.K. and Rao, T.V.J. (1997): In vitro antibiogram studies of Escherichia coli in chickens.Indian Vet.J.74:616-617.

- Venkanagouda, G.; Krishnappa G. and Upadhue A.S. (1996): Bacterial etiology of early chick mortality.Indian Vet. J., 73 (3):253256.

- Verma, K. C. and Adiakha, S. C. (1971): E. coli and other Enterobacteriaceae group of organisms from_different pathological condition in poultry. Ind. Vet . j., $48: 107$.

- Wasniewski, A. and Galazka, V. (1992): Baytril, bayer, a preparation for treatment of salmonella in poultry. Zeszyty Naukowe Akademiirolniczej we wroclawiu, weterynaria, 44:109-114.

- Younes, T.; youssef, H.; Abd El Karim, S. and Hassanein, K. (1990): Epidemiologiacal studies of pseudomonas aeruginosa in chickens, fish and human. Assiut Vet. Med., 23 (45): 48-56.

- Zakhary E.M.(1998): Microbiologica and semological Studies on an anion klebsiella spp. M. V. Sc, thesis, (Microbiology) Fac. of Vet. Med., Cairo University 


\section{الملخص العربي}

تعتبر الثروة الداجنة من أكثر الثزوات الحيوانية توفير اللبروثين الغذائي كمصدر حيواني وان من اخطر الأمراض التي نؤثر على هذه الثروة البكتريا المعوية التي تلعب دورا رئيسيا في نقص معدل التحويل الغذائي للطائر إلي جانب الخسائر المادية التي تتتج عن ارتفاع معدل الوفيات ومن هذا المنطلق تأتي هذه الدر اسة كححاولة مبسطة لإلقاء الضوء على ما يلي: 1. الكثف عن دور البكتيريا كعامل مساعد لارتفاع معدل الإسهال و النفوق في دو اجن التسمين 2. التــنيف البيوكيميائسي لــنلك لمسببات مع الاستعانة بنظام API 20 E في التصنيف البكتيري

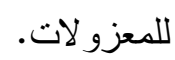

\section{3. التصنيف السيرولوجى لبعض من هذه المعزو لات.}

4. إيجاد أفضل المضادات البكتيرية لكي نستخدم في العلاج و المساعدة في وضع حد لهذه المشكلة. أجريت هذه الدراسة في محافظة الفيوم عن طريق اخذ العينات من مزارع منتشرة في مدن مختلفة بالمحافظة هي : ابشواي- اطسا- سنورس- طامية حيث نم تجميع 600 عينة مختلفة من فتحة المجمع ومن الكبد و المر ارة و القلب و الأمعاء من دو اجن النسمين في أعمار مختلفة والني أعطت 530 عينة ميكروبية لميكروبات مختلفة وكانت العينات عبارة عن 500 عينة من طيور بها علامات الإسهال المعوي و 100 عينة من طيور سليمة ظاهريا وقد أوضح الفحص البكتيريولوجي لهذه

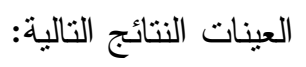
اظهـر الفحص البكتيري سيادة الميكروب القولوني الايشريشياكو لاي على الميكروبات الاخري وكانــت نـسبة عزلة 59.3\% منها 53.3\% من الطيور المصابة بالإسهال و 6\% من الطيور

السليمة ظاهريا. 
تــو الت الميكـروبات البكتيرية بعد ذلك فتم عزل ميكروب البروتيس مير ايبليس بنسبة 14.8\% مـنها 11.6\% من الطيور المصابة بالإسهال و 3.2\% من الطيور السليمة ظاهريا و ميكروب السالمونيلا بنسبة 5.2\% وميكروب الايروموناس هيدروفيلا بنسبة 3.2\% و ميكروب الكليبيلا بنـسبة 2.5\% وميكروب السودوموناس بنسبة 2.3\% وكانت كلها من طيور مصابة بالإسهال وميكـروب البــروتيس فولجاريز بنسبة 3.3\% منها 2.5\% من الطيور المصابة و 0.8\% من الطيور السليمة ظاهريا. وقــــــــر الفحص البكتيري لهذه الطيور وجود 85 حالة من الميكروبات المختلطة الني تجمع بين أكثر من ميكروب و احد في الطائر ويوضح الفحص البكتيري لهذه الميكروبات أن الميكروب القولوني هو صاحب الحظ الأوفر فى هـ

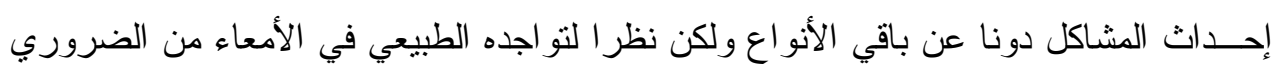
فصل تصنيف هذه العترة إلي مرضية أو غير مرضية ولهذا نم استخدام صبغة الكونجو الأحمر لهذا الغرض. وقد أظهرت النتائج أن نسبة وجود الميكروب القولوني الممرض بطيور دواجن التسمين هي 86\% (مستعمر ات حمر اء) و الغير ممرض وهي 14\% (مستعمرات بيضاء). تــم اسـتخدام نظام API 20 E لتصنيف البكتريا المعزولة وهو من الطرق الدقيقة و السريعة • للتصنيف البيوكيميائي تم إجر اء التصنيف السير ولوجي ل8 عتر ات من الميكروب القولوني وكانت النتيجة كالتالي : O مناثة عتر ات O114 K90.

$$
\begin{aligned}
& \text { O O26 K60 عترنان } \\
& \text { O مترنان O126 K71. } \\
& \text { O عترة واحدة - O91 K. } \\
& \text { م وباقي العثر ات لم يمكن تصنيفها. }
\end{aligned}
$$


كما تم تصنيف عشرة عتر ات من السلمونيلال للحصول علي نوعين هما :

$$
\begin{array}{r}
0 \\
0 \\
0
\end{array}
$$

كمـــا تــم فحــص كــلـ من ميكروبالابرومونس و السالمونيلا انتيرتيدس و و السالمونيلا فيرشاو و الإيــشرشياكو لاي لإختــبار الحـساسية وقد اتضـح ان ميكروب الايرومونساس كان كل من الجنتاميسين و الدوكسيسيكلين و النورفلوكساسين و الإنروفلوكساسين هم اقوي المضادات البكتيرية 100\% ثـم السيبروفلوكساسين و الكلور امفينيكول 75\% ثم كان السيفاليكسين و الكولسنين 50\% متوسـي الحسـاسة امـــا المقاومسـة فكانت لكل من الاموكسيسيلين و الامبيسيللين و النيومايسين و الإربيزرو مايسين. بيــنما كـــان ميكـروب الــسلمونيلا انتيــرتيدس شديد الحساسيه 100\% لكل من الجنتاميسين و النورفلوكـساسين و الإنروفلوكساسين و السيبروفلو كساسين و الكلور امفينيكول و الكولستين وكانت 75 مع النيومايسين و الدوكسيسيكلين أما فىحالة السيفالكسين فكانت متوسطة الحساسيه 50\% وكانت المقاومه مع الاموكسيسيلين و الامبيسيللين و الإريثرومايسين. أمـــا فــي حالة ميكروب السلمونيلا فيرشاو فكان شديد الحساسيه 100\% لكل من الجنتاميسين و النورفلوكـسـاسين و الإنروفلوكــاسين و السيبرو فلوكـسـاسين و الكلور امفينــيكول و النيو مايسين و الكولـسنتين وكانت 75\% مع الدوكسيسيكلين و السيفالكسين اما فى حالة الاموكسيسيلين فكانت متوسطة الحساسيه50\% وكانت المقاومه مع الامبيسيللين و الإريثرومايسين. وفــي حالــة ميكـروب الإشيرشــيا كو لاي فكان شديد الحساسيه 100\% لكل من الجنتاميسين و النورفلوكـسـاسين و الدوكسيـسيكلين وكانـــ 75\% مـــع الإنروفلوكساسين و الكلور امفينيكول و الكولـستين و السيفالكــين. امــا فى حالة السيبروفلوكساسين و الاموكسيسيلين فكانت متوسطة الحساسيه50\% وكانت المقاومه مع الامبيسيللين و الإريثرومايسين و النيومايسين. 